PANCREAS AND BILIARY

\title{
Use of microsatellite marker loss of heterozygosity in accurate diagnosis of pancreaticobiliary malignancy from brush cytology samples
}

\author{
A Khalid, R Pal, E Sasatomi, P Swalsky, A Slivka, D Whitcomb, S Finkelstein
}

Gut 2004;53:1860-1865. doi: 10.1136/gut.2004.039784

See end of article for authors' affiliations

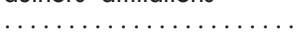

Correspondence to: Dr A Khalid, Division of Gastroenterology, Hepatology, and Nutrition, University of Pittsburgh Medical Center, M2 c-wing PUH, 200 Lothrop St, Pittsburgh, PA 15213 USA; khalid2@pitt.edu

Revised version received 4 March 2004

Accepted for publication 14 April 2004
Background: Brush cytology of biliary strictures to diagnose pancreaticobiliary malignancy suffers from poor sensitivity.

Aim: To improve the diagnostic yield of pancreaticobiliary brush cytology through analysis of tumour suppressor gene linked microsatellite marker loss of heterozygosity $(\mathrm{LOH})$ and k-ras codon 12 mutation detection.

Methods: Twenty six patients with biliary strictures underwent endoscopic retrograde cholangiography with brush cytology. A panel of 12 polymorphic microsatellite markers linked to six tumour suppressor genes was developed. Genomic DNA from cell clusters acquired from brush cytology specimens and microdissected surgical malignant and normal tissue underwent polymerase chain amplification reaction (PCR). PCR products were compared for $\mathrm{LOH}$ and k-ras codon 12 mutations.

Results: Seventeen patients were confirmed to have pancreaticobiliary adenocarcinoma. Nine patients had benign strictures (eight proven surgically, one by follow up). Cytomorphological interpretation was positive for malignancy $(n=8)$, indeterminate $(n=10)$, and negative for malignancy $(n=8)$. Selected malignant appearing cytological cell clusters and microdissected histological samples from cancer showed abundant $\mathrm{LOH}$ characteristic of malignancy while brushings from nine cases without cancer carried no $\mathrm{LOH}(p<0.001)$. LOH and $k$-ras mutations profile of the cytological specimens was almost always concordant with the tissue samples. Presence of $\mathrm{k}$-ras mutation predicted malignancy of pancreatic origin $(\mathrm{p}<0.001)$.

Conclusion: $\mathrm{LOH}$ and k-ras codon 12 mutation analysis of PCR amplified DNA from biliary brush cytology discriminates reactive from malignant cells, with 100\% sensitivity, specificity, and accuracy. Minor variations in $\mathrm{LOH}$ in brushings and in different sites within the same tumour likely reflect intratumoral mutational heterogeneity during clonal expansion of pre- and neoplastic lineages.
E arly and accurate diagnosis of pancreaticobiliary malignancy offers the best chance of a surgical cure while avoiding unnecessary major surgery in patients with benign disease. In many patients the first sign of a pancreaticobiliary cancer is a stricture of the bile duct. Currently, the diagnostic process includes an endoscopic retrograde cholangiography with brushings of the stricture to obtain cells used for cytological examination. The diagnosis of malignancy is based on cell morphology alone. However, a definitive diagnosis is impossible in many cases due to low cellularity, morphological changes induced by inflammation or necrosis, or technical variables in sample preparation associated with drying or cellular degradation during processing. Furthermore, a morphological diagnosis is subjective and observer dependent. Together, these factors result in a diagnostic test with low sensitivity $(<60 \%))^{1-5}$

The altered morphology of malignant cells reflects underlying genetic changes. The progressive morphological changes seen in the development of pancreatic ductal adenocarcinoma from normal cells has recently been modelled in the pancreatic intraductal neoplasia (PanIN) system. ${ }^{6}$ The strength of this system includes standardised pathological criteria for each progressive stage in tumour development linked with the underlying genetic aberrations. ${ }^{7-14}$ K-ras codon 12 mutations, for example, represent one of the earliest genetic changes in the development of pancreatic cancer ${ }^{15}{ }^{16}$ but there remains debate as to the exact frequency in bile duct cancer. ${ }^{17}{ }^{18}$ Sequential inactivation of tumour suppressor gene is also seen. This process can occur through a variety of processes, including gene mutation, hypermethylation, or loss of a chromosome or chromosomal segment containing the tumour suppressor gene. Any combination of these events will lead to loss of tumour suppressor gene activity. Tumour suppressor and related genes commonly lost in pancreaticobiliary cancers include TP53, p21, pl6Ink4a/ CDKN2A and DPC4/SMAD4, p53, and APC. ${ }^{19-39}$

We hypothesised that representative cells derived from malignant strictures would manifest a high level of accumulated mutational damage reflective of an underlying tumour, and that similar alterations would not be seen in cells reacting to an inflammatory process. As mutational screening of all relevant tumour suppressor genes from a few cytological cells is currently impossible in most diagnostic laboratories, and as a major cause of tumour suppressor gene inactivation is due to chromosomal loss (loss of heterozygosity, $\mathrm{LOH}$ ) we further hypothesised that detection of $\mathrm{LOH}$ from microsatellite markers closely linked to key genes would serve as an excellent surrogate marker for gene inactivation. Recognising that malignant strictures could be derived from pancreatic or biliary epithelial origin and that various tumour suppressor genes are lost at different stages of tumorigenesis and in only a subset of cancers requires that a broad panel of loci must be considered. The purpose of the current study was

Abbreviations: $\mathrm{LOH}$, loss of heterozygosity; WGA, whole genome amplification; CA, collective assembly; FMR, fractional mutation rate; $\mathrm{PCR}$, polymerase chain amplification reaction 
Table 1 Tumour suppressor genes (with associated markers) and k-ras-2 gene with chromosomal location and mutation type

\begin{tabular}{|c|c|c|c|c|}
\hline Gene & Locus & $\begin{array}{l}\text { Short arm } \\
\text { marker }\end{array}$ & $\begin{array}{l}\text { Long arm } \\
\text { marker }\end{array}$ & Mutation type \\
\hline $\begin{array}{l}\text { Retinoblastoma interacting zincfinger } \\
\text { (RIZ) }\end{array}$ & $1 p 36-1 p 34$ & D1S407 & MYCL & Deletion \\
\hline von Hippel-Lindau (VHL) & $3 p 26-3 p 25$ & D3S1539 & D3S2303 & Deletion \\
\hline Adenomatous polyposis coli (APC) & $5 q 23-5 q 23$ & D5S592 & D5S615 & Deletion \\
\hline CDKN2A/p16 & $9 p 21-9 p 23$ & D9S251 & D9S254 & Deletion \\
\hline $\begin{array}{l}\text { Phosphatase and Ten sin homologue } \\
\text { deleted on chromosome Ten (PTEN) } \\
\text { P53 } \\
\text { k-ras }\end{array}$ & $\begin{array}{l}10 q 23-10 q 23 \\
17 p 13-17 p 13 \\
12 p 12\end{array}$ & $\begin{array}{l}\text { D10S520 } \\
\text { D17S974 }\end{array}$ & $\begin{array}{l}\text { D10S1173 } \\
\text { D17S1289 }\end{array}$ & $\begin{array}{l}\text { Deletion } \\
\text { Deletion } \\
\text { Point mutation }\end{array}$ \\
\hline
\end{tabular}

to construct such a panel of LOH markers together with k-ras codon 12 activation mutation detection and to test this panel on brush cytology cells compared with surgical resected tumours, using normal cells from the same patient as internal controls.

\section{MATERIALS AND METHODS}

Twenty six patients with surgical $(n=25)$ or a long term disease free follow up $(n=1)$ were selected. Seventeen patients had surgically proven cancer (pancreatic adenocarcinoma $(n=6)$, cholangiocarcinoma $(n=11))$. Nine patients had an inflammatory process of which eight underwent surgical resection. Brush cytology was available for all patients which was recorded as malignant $(n=8)$, indeterminate $(n=10)$, and negative for malignancy $(n=8)$. Of the 10 patients with inconclusive cytology, one had a benign process and eight cases with a benign aetiology were reported "negative for malignant cells". The cytopathological criteria for malignancy included nuclear enlargement, pleomorphism (minimum of 3-4-fold variation in nuclear size), elevated N/C ratio, nuclear membrane irregularity, and coarse chromatin. ${ }^{40}$ Cases diagnosed as inconclusive fulfilled most but not all of the criteria for malignancy. The study was reviewed and approved by the University of Pittsburgh Medical Center, Institutional Review Board.

Cellular material from cytopathology and surgical pathology slides was collected by microdissection for $\mathrm{LOH}$ analysis and k-ras-2 point mutation determination. For cytology specimens, clusters of abnormal appearing cells were identified and marked on representative alcohol fixed Papanicolaou stained slides. Areas of interest were manually microdissected from the slides and placed in $25 \mu \mathrm{l}$ of dilute Tris buffer, $\mathrm{pH}$ 7.5. For surgical pathology slides, normal biliary tissue (negative control) and neoplastic areas were manually microdissected from all malignant (17) and two benign cases. Normal tissue samples were run to determine normal microsatellite heterozygosity as well as to serve as an internal negative control for mutational damage.

In some cases, only a small number of abnormal appearing cells were identified on brush cytology slides. Therefore, two different approaches were used for $\mathrm{LOH}$ analysis and the results compared. The first approach, termed collective assembly (CA), involved combining separate aggregates of abnormal appearing cell clusters into a single storage sample of sufficient cellular content to allow for direct polymerase chain amplification reaction (PCR). A minimum of approximately 1000 cells was necessary for sufficient genomic DNA for this type of direct analysis. The CA approach thus produced an averaging of mutational change among the aggregated microdissected cells. The second approach, termed whole genome amplification (WGA), consisted of microdissection of discrete clusters of 50-100 cells representing individual cytological lesions. In order to obtain sufficient
DNA substrate for broad panel genotyping, WGA was performed prior to individual marker PCR amplification and analysis. ${ }^{41}{ }^{42}$ Two to three separate WGA were carried out on individual cases. The WGA approach could be applied in situations of scant cellularity where inadequate cells were present for the CA approach. Also, the WGA method was considered theoretically capable of providing data on intratumoral heterogeneity and cancer clonal expansion so that the different microdissected samples could be compared with each other to gain additional insight into tumorigenesis and cancer biology. WGA, however, introduced an intermediary step that could introduce artefacts into final mutational profiling and therefore was directly compared with the results of CA. WGA was performed as previously reported using the degenerate oligonucleotide primed-PCR technique. ${ }^{42} 43$

Aliquots $(1 \mu \mathrm{l})$ of CA DNA or WGA PCR products were used in the PCR for a broad panel of microsatellite markers potentially commonly involved in human pancreatic and biliary carcinogenesis. Tumour suppressor gene LOH was determined by analysis of tightly linked informative polymorphic microsatellites. The tumour suppressor genes selected are given in table 1 . Use of two markers within each locus was used to increase the likelihood that at least one of the markers would be polymorphic within a subject, and thus informative for $\mathrm{LOH}$ analysis.

A microsatellite is a region of genomic DNA with a string of $1-4$ bases that are repeated over a short distance. The number of repeats and a locus is often variable between alleles so that each chromosome can be identified and traced. Since tens of thousands of microsatellites with heterogeneous sizes span the human genome it is possible to choose highly heterogeneous microsatellites as chromosomal markers at loci that immediately flank tumour suppressor genes or other genes of interest. LOH (for example, either the shorter or longer microsatellite is missing) suggests that one of the two chromosomal arms has been lost. The implication is that a mutation of the tumour suppressor gene on the opposite chromosome occurred because the clone of tumour cells with this combination of $\mathrm{LOH}$ and a tumour suppressor gene mutation would provide a growth advantage.

PCR amplification was designed to generate amplicons of less than 200 base pairs long using synthetic oligonucleotide primers flanking each microsatellite. Oligonucleotide primers were created with $5^{\prime}$ fluorescent moieties (FAM, HEX, NED) suitable for automated fragment analysis. PCR products were analysed by capillary electrophoresis on an ABI 3100 according to manufacturer's instructions (Applied Biosystems, Foster City, California, USA). Allele peak heights and lengths were used to define the presence or absence of allelic imbalance (that is, $\mathrm{LOH}$ ) for a given sample. Allelic imbalance was reported when the ratio of polymorphic allelic bands for a particular marker was below 0.5 or above $2.0 .^{44} \mathrm{In}$ 
addition, the deleted allele was designated as either " $\mathrm{B}$ " or " $\mathrm{T}$ " depending on whether the bottom (longer length) or top (shorter length) microsatellite allele was diminished compared with the subject's normal DNA profile. This was important as the presence of the identical deleted allele in different microdissection targets supported the existence of the same deletion in all affected target sites. Similarly, it was possible to identify two separate mutations of the same genomic region in different topographic tissue samples when deleted alleles were shown to be discordant. A locus was determined to be concordant when the same allele was lost (for example, LOH B in the cytology specimen and the surgical specimen).

In addition to allelic loss analysis, DNA sequencing of k-ras-2 exon 1 PCR amplified DNA was used to search for and characterise point mutations in codons 12 and 13 . Overall genotyping analysis thus represented a combination of point mutational and allelic loss damage (table 1).

\section{Statistical analysis}

The fractional mutation rate (FMR), defined as the number of mutated markers (k-ras-2 point mutation with or without significant allelic imbalance) divided by the total number of informative microsatellite markers ${ }^{45}{ }^{46}$ plus $\mathrm{l}$ for k-ras-2 status, was used as a measure of overall mutation accumulation. Recognising that each patient possessed his/her own unique panel of informative polymorphic microsatellite markers, the FMR served as a means of comparing patients to each other with respect to the extent of cumulative acquired mutational damage. Mean number of mutations between the positive and inconclusive cytology was compared using a two independent sample $t$ test. Comparison of mutations between malignant and benign samples utilised the non-parametric two sample Mann-Whitney $U$ test because of unequal variances. The $\chi^{2}$ test was used to contrast specific mutational patterns in neoplastic tissue of pancreatic versus biliary origin.

\section{RESULTS}

Microsatellite polymorphic profiles were determined in normal tissue from all patients. In all patients with cancer and two with no cancer, genotyping data were available on a non-neoplastic sample from the subsequent tissue resection. Normal appearing cellular material from the brush cytology was used in the remaining patients. None of the nonneoplastic tissue targets showed evidence of allelic loss in multiple sampling, as defined by threshold criteria (see materials and methods). Data regarding the presence or absence of k-ras-2 point mutational changes were available for all patients.

All 17 patients with cancer in resected tissue specimens had multiple loci with LOH compared with their own normal tissue, with or without k-ras-2 point mutational change, yielding a sensitivity of $100 \%$. Using tissue specimens of resected cancer, FMR ranged from 0.30 to 0.85 . There was no LOH or k-ras-2 point mutations in any of the microdissected samples obtained from the nine subjects without cancer $(\mathrm{p}<0.001)$ (table 2$)$.

Mutational analysis of cytological specimens from cancer yielded multiple losses, the FMR ranging from 0.3 to 0.7 (average 0.45 ) for positive and from 0.3 to 0.7 (average 0.38) for indeterminate samples, without significant difference. The presence of $\mathrm{k}$-ras mutations was associated with pancreatic cancer (5/6) and not cholangiocarcinoma (0/11) and this difference was significant $(\mathrm{p}<0.001)$.

The pattern of allelic loss and k-ras-2 point mutational damage in all microdissected cytology samples closely correlated with the corresponding tissue specimens. In all cases where a k-ras-2 point mutation was identified in the resected tissue samples, the identical k-ras-2 mutated alteration was present in the cytology specimens using both the CA and WGA approach. In some cases, the mutational profile defined by cytological specimens was a perfect match to that obtained from microdissected tissue samples. More often, however, slight variations in the mutational profile were evident between the cytological and histological

Table 2 Detailed information on all cases, including tumour type and associated genes with allelic loss for various tissue

\begin{tabular}{|c|c|c|c|c|c|}
\hline $\begin{array}{l}\text { Case } \\
\text { No }\end{array}$ & Pathology & Cytology & Path-LOH* & Cyto-LOH† & Normal-LOH $\ddagger$ \\
\hline 1 & Pancreatic cancer & Positive & k-ras,RIZ,VHL,PTEN,P53 & k-ras,RIZ,VHL,PTEN,P53 & No LOH \\
\hline 2 & Pancreatic cancer & Positive & k-ras,RIZ,VHL,P16,P53 & k-ras,RIZ,P16,P53 & No LOH \\
\hline 3 & Pancreatic cancer & Positive & $\mathrm{RIZ,P16}$ & $\mathrm{RIZ,P16}$ & $\mathrm{No} \mathrm{LOH}$ \\
\hline 4 & Pancreatic cancer & Positive & k-ras, VHL,APC,P16,PTEN & k-ras,VHL,APC,P16,PTEN & No LOH \\
\hline 5 & Cholangiocarcinoma & Positive & VHL,APC,P16,P53 & VHL,APC,P16,P53 & No LOH \\
\hline 6 & Cholangiocarcinoma & Positive & APC,PTEN & APC,PTEN & $\mathrm{No} \mathrm{LOH}$ \\
\hline 7 & Cholangiocarcinoma & Positive & VHL,PTEN,P53 & VHL,PTEN,P53 & No LOH \\
\hline 8 & Cholangiocarcinoma & Positive & RIZ,APC,PTEN & $\mathrm{RIZ}, \mathrm{VHL}, \mathrm{APC}, \mathrm{PTEN}$ & No LOH \\
\hline 9 & Pancreatic cancer & Inconclusive & k-ras, VHL,APC,P16,P53 & k-ras, VHL,APC,P16,P53 & No LOH \\
\hline 10 & Pancreatic cancer & Inconclusive & k-ras, VHL,APC & k-ras, VHL,APC & No LOH \\
\hline 11 & Cholangiocarcinoma & Inconclusive & $\mathrm{RIZ}, \mathrm{APC}$ & $\mathrm{RIZ}, \mathrm{APC}$ & No LOH \\
\hline 12 & Cholangiocarcinoma & Inconclusive & APC,P16,PTEN & VHL,APC,P16,PTEN & No LOH \\
\hline 13 & Cholangiocarcinoma & Inconclusive & $\mathrm{RIZ}, \mathrm{VHL}, \mathrm{P} 16, \mathrm{P} 53$ & VHL,P53 & No LOH \\
\hline 14 & Cholangiocarcinoma & Inconclusive & RIZ,APC,P16,PTEN & RIZ,APC,P16,PTEN & No LOH \\
\hline 15 & Cholangiocarcinoma & Inconclusive & VHL,P16,P53 & P16,P53 & No LOH \\
\hline 16 & Cholangiocarcinoma & Inconclusive & RIZ,APC,PI6,PTEN & APC,P16,PTEN & $\mathrm{No} \mathrm{LOH}$ \\
\hline 17 & Cholangiocarcinoma & Inconclusive & RIZ,PTEN,P53 & RIZ,PTEN & No LOH \\
\hline 18 & Inflammatory & Inconclusive & No PATH & No $\mathrm{LOH}$ & No LOH \\
\hline 19 & Inflammatory & Benign & No LOH & $\mathrm{No} \mathrm{LOH}$ & $\mathrm{No} \mathrm{LOH}$ \\
\hline 20 & Inflammatory & Benign & No LOH & No LOH & \\
\hline 21 & Inflammatory & Benign & & No LOH & \\
\hline 22 & Inflammatory & Benign & & No LOH & \\
\hline 23 & Inflammatory & Benign & & No LOH & \\
\hline 24 & Inflammatory & Benign & & No LOH & \\
\hline 25 & Inflammatory & Benign & & No LOH & \\
\hline 26 & Inflammatory & Benign & & No LOH & \\
\hline
\end{tabular}

*Path-LOH, loss of heterozygosity $(\mathrm{LOH})$ in the surgically resected tumour, following microdissection. †Cyto- $\mathrm{LOH}, \mathrm{LOH}$ in cells from the cytology specimen.

$\ddagger$ Normal- $\mathrm{LOH}, \mathrm{LOH}$ in normal tissue adjacent to the tumour. 
Table 3 Example of microdissection genotyping, manifesting perfect concordance of mutational change between cytological samples (by both the CA method and the WGA approach) and the surgical specimen

\begin{tabular}{|c|c|c|c|c|c|}
\hline Gene & $\begin{array}{l}\text { Non-neoplastic } \\
\text { tissue }\end{array}$ & $\begin{array}{l}\text { Positive cytology } \\
(\mathrm{CA})^{*}\end{array}$ & $\begin{array}{l}\text { Positive cytology } \\
\text { (WGA) }\end{array}$ & $\begin{array}{l}\text { Positive cytology } \\
\text { (WGA) }\end{array}$ & $\begin{array}{l}\text { Histology } \\
\text { tumour }\end{array}$ \\
\hline RIZ & $\mathrm{NI}$ & $\mathrm{NI}$ & $\mathrm{NI}$ & $\mathrm{NI}$ & $\mathrm{NI}$ \\
\hline RIZ & I & LOH T & LOH T & LOH T & LOH T \\
\hline VHL & I & LOH B & LOH B & LOH B & LOH B \\
\hline VHL & $\mathrm{NI}$ & $\mathrm{NI}$ & $\mathrm{NI}$ & $\mathrm{NI}$ & $\mathrm{NI}$ \\
\hline APC & 1 & No LOH & No LOH & No LOH & No LOH \\
\hline APC & i & No LOH & No $\mathrm{LOH}$ & No LOH & No $\mathrm{LOH}$ \\
\hline P16 & i & No LOH & No LOH & No $\mathrm{LOH}$ & No LOH \\
\hline P16 & I & No LOH & No LOH & No $\mathrm{LOH}$ & No LOH \\
\hline PTEN & i & LOH B & LOH B & LOH B & LOH B \\
\hline PTEN & i & LOH B & LOH B & LOH B & LOH B \\
\hline KRAS & No MUT & 12G-R & 12G-R & $12 \mathrm{G}-\mathrm{R}$ & 12G-R \\
\hline P53 & $\mathrm{NI}$ & $\mathrm{NI}$ & $\mathrm{NI}$ & $\mathrm{NI}$ & $\mathrm{NI}$ \\
\hline P53 & 1 & LOH T & LOH T & LOH T & LOH T \\
\hline \multicolumn{6}{|c|}{$\begin{array}{l}\text { *CA, collective assembly in which multiple discrete clusters of target cells are aggregated together into one common } \\
\text { pool from which aliquots are taken for broad panel mutational genotyping. } \\
\text { †WGA, whole genome amplification in which a single cluster of cells is first subject to general amplification using } \\
\text { random oligonucleotide primers. } \\
\text { NI, non-informative marker status (see materials and methods for further details); I, informative marker. }\end{array}$} \\
\hline
\end{tabular}

material. These difference were interpreted as minor mutational profile variations from intratumoral heterogeneity, given that the specimens were taken from different parts of the tumour within each case. ${ }^{47} 48$ Two examples of microdissection genotyping from the series are shown in tables 3 and 4 . The patient displayed in table 3 manifested a perfect concordance of mutational change between cytological samples obtained by both the CA method and the WGA approach. Genotyping results from the patient shown in table 4 revealed a minor degree of discordance affecting two markers from six that exhibited mutational change. Despite these slight differences, the majority of mutational change was concordant between the different samples of tumour.

All cases characterised as suspicious or atypical for malignancy by cytomorphology alone could be shown to manifest a profile of accumulated mutational damage equivalent to that seen in proven pancreaticobiliary cancer. Irrespective of the reasons for indeterminate status, the resulting profile of accumulated mutated markers was sufficiently precise to afford firm correlation with ultimate malignancy, as established in tissue specimens based on both cellular morphology and cumulative mutational profile.

\section{DISCUSSION}

Cytological diagnosis of pancreaticobiliary cancer can be challenging, especially with a high rate of indeterminate diagnoses using brush cytology. Molecular approaches, such as the one described here, provide an independent determination of the presence and extent of mutational damage that underlie malignant transformation. ${ }^{49} 50$ The sensitivity, specificity, and accuracy of our technique are $100 \%$.

Two methods were used to collect cytological samples for molecular analysis. The collective assembly (CA) approach enabled direct application of genotyping to aggregated representative cells and thus closely paralleled the tissue based mutational analysis. The CA method has two important drawbacks. The first is the requirement for relatively abundant cellular material as broad panel mutational genotyping demands that the sample be subdivided for individual mutational analyses. Abundance of cellular material is one of the limitations in standard morphological analysis of cytology specimens which was the reason for using an alternative molecular approach for diagnostic assistance. The second drawback of the CA method is the averaging between different cellular clusters that are aggregated together as

\begin{tabular}{|c|c|c|c|c|c|}
\hline Gene & $\begin{array}{l}\text { Non-neoplastic } \\
\text { tissue }\end{array}$ & 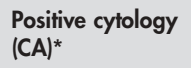 & $\begin{array}{l}\text { Positive cytology } \\
\text { (WGA) }\end{array}$ & $\begin{array}{l}\text { Positive cytology } \\
\text { (WGA) }\end{array}$ & $\begin{array}{l}\text { Histology } \\
\text { tumour }\end{array}$ \\
\hline RIZ & $\mathrm{NI}$ & $\mathrm{NI}$ & $\mathrm{NI}$ & $\mathrm{NI}$ & $\mathrm{NI}$ \\
\hline RIZ & 1 & LOH T & LOH T & LOH T & LOH T \\
\hline VHL & I & No LOH & LOH B & LOH B & LOH B \\
\hline VHL & 1 & LOH T & No LOH & No $\mathrm{LOH}$ & LOH T \\
\hline APC & $\mathrm{NI}$ & $\mathrm{NI}$ & $\mathrm{NI}$ & $\mathrm{NI}$ & $\mathrm{NI}$ \\
\hline APC & $\mathrm{NI}$ & $\mathrm{NI}$ & $\mathrm{NI}$ & $\mathrm{NI}$ & $\mathrm{NI}$ \\
\hline P16 & 1 & No LOH & No LOH & No LOH & No LOH \\
\hline P16 & 1 & LOH T & LOH T & LOH T & LOH T \\
\hline PTEN & $\mathrm{NI}$ & $\mathrm{NI}$ & $\mathrm{NI}$ & $\mathrm{NI}$ & $\mathrm{NI}$ \\
\hline PTEN & $\mathrm{NI}$ & $\mathrm{NI}$ & $\mathrm{NI}$ & $\mathrm{NI}$ & $\mathrm{NI}$ \\
\hline KRAS & No MUT & 12G-D & 12G-D & 12G-D & 12G-D \\
\hline P53 & $\mathrm{NI}$ & $\mathrm{NI}$ & $\mathrm{NI}$ & $\mathrm{NI}$ & $\mathrm{NI}$ \\
\hline P53 & 1 & LOH B & LOH B & LOH B & LOH B \\
\hline
\end{tabular}

*CA, collective assembly in which multiple discrete clusters of target cells are aggregated together into one common pool from which aliquots are taken for broad panel mutational genotyping.

tWGA, whole genome amplification in which a single cluster of cells is first subject to general amplification using random oligonucleotide primers.

$\mathrm{NI}$, non-informative marker status (see materials and methods for further details); I, Informative marker. 
part of one sample that then is subdivided for broad panel mutational genotyping. This would have the effect of obscuring intratumoral mutational heterogeneity while favouring the detection of those alterations that arose early in tumorigenesis and are present throughout the majority of cancer cells.

The whole genome amplification technique (WGA) for analysing individual cytology cell clusters does not suffer from these drawbacks but itself could suffer from the problem of artefactual allelic imbalance introduced during the pre-genotyping amplification step. This important drawback is well recognised and must be carefully evaluated when the technique is used. Our approach was to carry out replicate analyses on both positive and negative results for each patient and to require that all such testing be shown to be consistent. Thus WGA appears to be useful for $\mathrm{LOH}$ analysis and point mutation analysis.

Although specific mutational damage can occur in reactive states of cellular proliferation (for example, k-ras-2 point mutations in chronic pancreatitis without evidence of malignancy ${ }^{51}$ ), most malignancies, including pancreatic cancer, manifest abundant somatically acquired DNA mutational alterations in keeping with their neoplastic phenotype. In most systems, the level of accumulated mutations is significantly higher in frank cancer than in precancerous lesions, dysplastic states, or benign disease. It is reasonable to contend that objective thresholds for accumulated DNA mutational damage can be formulated that discriminate between non-neoplastic reactive states versus malignancy with a high degree of confidence. A further insight from our results is the lack of k-ras mutations in biliary malignancy compared with pancreatic adenocarcinoma, thus patterns of mutation accrual in biliary strictures may help predict the origin of the underlying neoplasm.

In conclusion, a microdissection genotyping approach organised in series to follow cytological analysis can provide valuable information without jeopardising morphological interpretation. Commonly deleted chromosomal regions harbouring potential tumour suppressor genes can be detected by loss of heterozygosity ( $\mathrm{LOH}$ ) analysis using PCR amplification of polymorphic microsatellite repeats in tumour and matched normal DNA. When LOH analysis is extended to multiple chromosomal arms, a distinct allelotype is generated reflecting the malignant status of the corresponding cells and providing a potential independent and objective marker of malignancy. The overwhelming concordance in allelic loss and k-ras-2 point mutational change provides validation that molecular profiling of cytological specimens reflects an accurate and detailed picture of mutation acquisition unique to an individual patient's tumour. The presence, extent, and pattern of acquired mutation damage in selected cell populations of endoscopic brush cytology provide meaningful discriminatory information for the improved diagnosis of pancreaticobiliary cancer. We recommend and foresee the application of such molecular techniques to reach a definitive diagnosis in the setting of inconclusive brush cytology. This will potentially avoid further invasive tests in patients with biliary strictures and expedite appropriate management.

\section{Authors' affiliations}

A Khalid, A Slivka, D Whitcomb, Division of Gastroenterology and Hepatology, University of Pittsburgh, Pittsburgh, USA

R Pal, E Sasatomi, P Swalsky, S Finkelstein, Department of Pathology, University of Pittsburgh, Pittsburgh, USA

\section{REFERENCES}

1 Stewart CJ, Mills PR, Carter R, et al. Brush cytology in the assessment of pancreatico-biliary strictures: a review of 406 cases. J Clin Pathol 2001;54:449-55
2 Pugliese V, Pujic N, Saccomanno S, et al. Pancreatic intraductal sampling during ERCP in patients with chronic pancreatitis and pancreatic cancer: cytologic studies and k-ras-2 codon 12 molecular analysis in 47 cases. Gastrointest Endosc 2001;54:595-9.

3 Farrell RJ, Jain AK, Brandwein SL, et al. The combination of stricture dilation, endoscopic needle aspiration, and biliary brushings significantly improves diagnostic yield from malignant bile duct strictures. Gastrointest Endosc 2001;54:587-94.

4 Macken E, Drijkoningen $M$, Van Aken E, et al. Brush cytology of ductal strictures during ERCP. Acta Gastroenterol Belg 2000;63:254-9.

5 Glasbrenner B, Ardan M, Boeck W, et al. Prospective evaluation of brush cytology of biliary strictures during endoscopic retrograde

6 Hruban RH, Adsay NV, Albores-Saavedra J, et al. Pancreatic intraepithelial neoplasia: a new nomenclature and classification system for pancreatic duct lesions. Am J Surg Pathol 2001;25:579-86.

7 Apple SK, Hecht JR, Lewin DN, et al. Immunohistochemical evaluation of Kras, p53, and HER-2/neu expression in hyperplastic, dysplastic, and carcinomatous lesions of the pancreas: evidence for multistep carcinogenesis. Hum Pathol 1999;30:123-9.

8 Schmid RM. Genetic basis of pancreatic cancer. Balliers Best Pract Res Clin Gastroenterol 2002;16:421-33.

9 Rozenblum E, Schutte M, Goggins $M$, et al. Tumor suppressive pathways in pancreatic carcinoma. Cancer Res 1997;57:1731-4.

10 Mizumoto K, Tanaka M. Genetic diagnosis of pancreatic cancer $J$ Hepatobiliary Pancreat Surg 2002;9:39-44.

11 Griffin CA, Hruban RH, Morsberger LA, et al. Consistent chromosome abnormalities in adenocarcinoma of the pancreas. Cancer Res 1995;55:2394-9.

12 Rashid A. Cellular and molecular biology of biliary tract cancers. Surg Oncol Clin N Am 2002;11:995-100.

$13 \mathrm{Ku} \mathrm{JL}$, Yoon KA, Kim IJ, et al. Establishment and characterization of six human biliary tract cancer cell lines. Br J Cancer 2002;87:187-93.

14 Kang YK, Kim YI, Kim WH. Allelotype analysis of intrahepatic cholangiocarcinoma. Mod Pathol 2000;13:627-31.

15 Almoguera C, Shibata D, Forrester K, et al. Most human carcinomas of the exocrine pancreas contain mutant c-K-ras genes. Cell 1988;53:549-54.

16 Caldas C, Kern SE. K-ras mutation and pancreatic adenocarcinoma. Int J Pancreatol 1995; 18:1-6.

17 Motojima K, Tsunoda T, Kanematsu T, et al. Distinguishing pancreatic carcinoma from other periampullary carcinomas by analysis of mutations in the Kirsten-ras oncogene. Ann Surg 1991;214:657-62.

18 Tsuda H, Satarug S, Bhudhisawasdi V, et al. Cholangiocarcinomas in Japanese and Thai patients: difference in etiology and incidence of point mutation of the c-Ki-ras proto-oncogene. Mol Carcinog 1992;6:266-9.

19 Boschman CR, Stryker S, Reddy JK, et al. Expression of p53 protein in precursor lesions and adenocarcinoma of human pancreas. Am J Pathol 1994;145:1291-5.

20 Redston MS, Caldas C, Seymour AB, et al. p53 mutations in pancreatic carcinoma and evidence of common involvement of homocopolymer tracts in DNA microdeletions. Cancer Res 1994;54:3025-33.

21 Barton CM, Staddon SL, Hughes CM, et al. Abnormalities of the p53 tumor suppressor gene in human pancreatic cancer. Br J Cancer 1991:64:1076-82.

22 Biankin AV, Kench JG, Morey AL, et al. Overexpression of p21 (WAF1/CIP1) is an early event in the development of pancreatic intraepithelial neoplasia. Cancer Res 2001;61:8830-7.

23 Caldas C, Hahn SA, da Costa LT, et al. Frequent somatic mutations and homozygous deletions of the p16 (MTS1) gene in pancreatic adenocarcinoma. Nat Genet 1994;8:27-32.

24 Goldstein AM, Fraser MC, Struewing JP, et al. Increased risk of pancreatic cancer in melanoma-prone kindreds with pl6INK4 mutations. N Engl J Med 1995; 333:970-4.

25 Wilentz RE, lacobuzio-Donahue CA, Argani P, et al. Loss of expression of Dpc4 in pancreatic intraepithelial neoplasia: evidence that DPC4 inactivation occurs late in neoplastic progression. Cancer Res 2000;60:2002-6.

26 Hahn SA, Schutte M, Hoque AT, et al. DPC4, a candidate tumor suppressor gene at human chromosome 18q21.1. Science 1996;271:350-3.

27 Luttges J, Galehdari H, Brocker V, et al. Allelic loss is often the first hit in the biallelic inactivation of the p53 and DPC4 genes during pancreatic carcinogenesis. Am J Pathol 2001;158:1677-83.

28 Taniai $M$, Higuchi $\mathrm{H}$, Burgart $\mathrm{U}$, et al. pl6INK4a promoter mutations are frequent in primary sclerosing cholangitis (PSC) and PSC-associated cholangiocarcinoma. Gastroenterology 2002;123:1090-8.

29 Isa T, Tomita S, Nakachi A, et al. Analysis of microsatellite instability, K-ras gene mutation and $\mathrm{p} 53$ protein overexpression in intrahepatic cholangiocarcinoma. Hepatogastroenterology 2002:49:604-8.

30 Ahrendt SA, Rashid A, Chow JT, et al. p53 overexpression and K-ras gene mutations in primary sclerosing cholangitis-associated biliary tract cancer. $J$ Hepatobiliary Pancreat Surg 2000;7:426-31.

31 Ding SF, Delhanty JD, Bowles L, et al. Loss of constitutional heterozygosity on chromosomes 5 and 17 in cholangiocarcinoma. Br J Cancer 1993;67:1007-10.

32 Kang YK, Kim WH, Lee HW, et al. Mutation of p53 and K-ras, and loss of heterozygosity of APC in intrahepatic cholangiocarcinoma. Lab Invest 1999;79:477-83.

33 Kiba T, Tsuda H, Pairojkul C, et al. Mutations of the p53 tumor suppressor gene and the ras gene family in intrahepatic cholangiocellular carcinomas in Japan and Thailand. Mol Carcinog 1993;8:312-18.

34 Levi S, Urbano-Ispizua A, Gill R, et al. Multiple K-ras codon 12 mutations in cholangiocarcinomas demonstrated with a sensitive polymerase chain reaction technique. Cancer Res 1991:51:3497-502.

35 Ohashi K, Nakajima Y, Kanehiro H, et al. Ki-ras mutations and p53 protein expressions in intrahepatic cholangiocarcinomas: relation to gross fumor morphology. Gastroenterology 1995;109:1612-17. 
36 Tada $M$, Omata $M$, Ohto $M$. High incidence of ras gene mutation in intrahepatic cholangiocarcinoma. Cancer 1992;69:1115-18.

37 Yoshida S, Todoroki T, Ichikawa Y, et al. Mutations of p16 1NK4/CDKN2 and p1 $5^{\text {INK } 4 \mathrm{~B}} /$ MTS2 genes in biliary tract cancers. Cancer Res $1995 \cdot 55 \cdot 2756-60$

38 Hruban RH, Wilentz RE, Kern SE. Genetic progression in the pancreatic ducts. Am J Pathol 2000; 156:18215.

39 Khalid A, Whitcomb DC. The premalignant lesions for pancreatic cancer; will Pan-IN's pan out? Gastroenterology 2002;123:645-7.

40 Solcia E, Capella C, Kloppel G. Tumors of the pancreas, atlas of tumor pathology. Washington DC: Armed Forces Institute of Pathology, American Registry of Pathology, 1997.

41 Hawkins TL, Detter JC, Richardson PM. Whole genome amplificationapplications and advances. Curr Opin Biotechnol 2002;13:65-7.

42 Barbaux S, Poirier O, Cambien F. Use of degenerate oligonucleotide primed PCR (DOP-PCR) for the genotyping of low-concentration DNA samples. J Mol Med $2001 ; 79: 329-32$.

43 Larsen J, Ottesen AM, Lundsteen C, et al. Optimization of DOP-PCR amplification of DNA for high-resolution comparative genomic. Cytometry $2001 ; 44: 317$.

44 Rolston R, Sasatomi E, Hunt J, et al. Distinguishing de novo second cancer formation from tumor recurrence: mutational fingerprinting by microdissection genotyping. J Mol Diagn 2001;3:129-32.
45 Vogelstein B, Fearon ER, Kern SE, et al. Allelotype of colorectal carcinomas. Science 1989;244:217-21.

46 van Heek T, Rader AE, Offerhaus GJ, et al. K-ras, p53, and DPC4 (MAD4) alterations in fine-needle aspirates of the pancreas: a molecular panel correlates with and supplements cytologic diagnosis. Am J Clin Pathol 2002;117:755-65.

47 Gorunova L, Hoglund M, Andren-Sandberg A, et al. Cytogenetic analysis of pancreatic carcinomas: intratumor heterogeneity and nonrandom pattern of chromosome aberrations. Genes Chromosomes Cance 1998:23:8199.

48 Harada T, Okita K, Shiraishi K, et al. Interglandular cytogenetic heterogeneity detected by comparative genomic hybridization in pancreatic cancer. Cancer Res 2002;62:8359

49 Ohori P, Khalid A, Etemad B, et al. Multiple loss of heterozygosity without kras mutation identified by molecular analysis on fine needle aspiration cytology specimen of acinar cell carcinoma of pancreas. Diagn Cytopathol 2002;27:42-6

50 Tada M, Omata M, Kawai S, et al. Detection of ras gene mutations in pancreatic juice and peripheral blood of patients with pancreatic adenocarcinoma. Cancer Res 1993:53:2472-4.

51 Tada M, Ohashi M, Shiratori Y, et al. Analysis of K-ras gene mutation in hyperplastic duct cells of the pancreas without pancreatic disease. Gastroenterology 1996;10:227-31.

\section{Clinical Evidence - Call for contributors}

Clinical Evidence is a regularly updated evidence-based journal available worldwide both as a paper version and on the internet. Clinical Evidence needs to recruit a number of new contributors. Contributors are healthcare professionals or epidemiologists with experience in evidence-based medicine and the ability to write in a concise and structured way.

Areas for which we are currently seeking authors:

- Child health: nocturnal enuresis

- Eye disorders: bacterial conjunctivitis

- Male health: prostate cancer (metastatic)

- Women's health: pre-menstrual syndrome; pyelonephritis in non-pregnant women

However, we are always looking for others, so do not let this list discourage you.

Being a contributor involves:

- Selecting from a validated, screened search (performed by in-house Information Specialists) epidemiologically sound studies for inclusion.

- Documenting your decisions about which studies to include on an inclusion and exclusion form, which we keep on file.

- Writing the text to a highly structured template (about 1500-3000 words), using evidence from the final studies chosen, within 8-10 weeks of receiving the literature search.

- Working with Clinical Evidence editors to ensure that the final text meets epidemiological and style standards.

- Updating the text every six months using any new, sound evidence that becomes available. The Clinical Evidence in-house team will conduct the searches for contributors; your task is simply to filter out high quality studies and incorporate them in the existing text.

- To expand the topic to include a new question about once every 12-18 months.

If you would like to become a contributor for Clinical Evidence or require more information about what this involves please send your contact details and a copy of your CV, clearly stating the clinical area you are interested in, to Klara Brunnhuber (kbrunnhuber@ bmigroup.com).

\section{Call for peer reviewers}

Clinical Evidence also needs to recruit a number of new peer reviewers specifically with an interest in the clinical areas stated above, and also others related to general practice. Peer reviewers are healthcare professionals or epidemiologists with experience in evidence-based medicine. As a peer reviewer you would be asked for your views on the clinical relevance, validity, and accessibility of specific topics within the journal, and their usefulness to the intended audience (international generalists and healthcare professionals, possibly with limited statistical knowledge). Topics are usually 1500-3000 words in length and we would ask you to review between 2-5 topics per year. The peer review process takes place throughout the year, and our turnaround time for each review is ideally 10-14 days.

If you are interested in becoming a peer reviewer for Clinical Evidence, please complete the peer review questionnaire at www.clinicalevidence.com or contact Klara Brunnhuber (kbrunnhuber@bmigroup.com). 